\title{
Development of a new resource-saving technology of rye-wheat bread on liquid rye sourdoughs using recycled bread
}

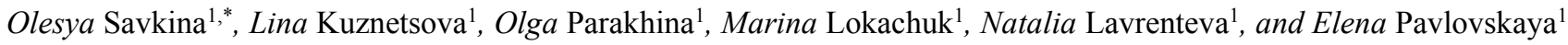 \\ ${ }^{1}$ St. Petersburg branch State Research Institute of Baking Industry, Podbelskogo highway 7, 196608, St.Petersburg, Pushkin, Russian \\ Federation
}

\begin{abstract}
Recycling of substandard bread, technological waste and bread from the distribution network is a promising way of waste management and raw materials saving. In order to optimize the old bread recycling process and to improve the quality of finished products, a new resource-saving technology for rye-wheat bread was developed. It was found that use under $25 \%$ of bread crumbs instead of flour was possible in a liquid sourdough with a moisture content of $70 \%$. When old bread dosage increased from 50 to $100 \%$, acid accumulation slowed down, the lifting force deteriorated, the viscosity increased, which may makes it difficult or impossible to pump the sourdough in industrial technological process. The liquid sourdough made with $25 \%$ of old bread had a better lifting capacity and contained more alcohol and volatile acids than the control. The quality of bread made using sourdough with $25 \%$ of old bread was comparable in quality to control bread made using traditional sourdough. Liquid rye sourdough with recycled old bread allowed the bread shelf life extension by slowing down the bread staling. No effect on mold rate was found when using recycled old bread in sourdough.
\end{abstract}

\section{Introduction}

Bread is a product that is produced and consumed almost in all countries over the world. The industrial bread production can be accompanied by significant losses due to technological defects, substandard bread, returns from the distribution network. The introduction of resourcesaving technologies into the existing bakery enterprises can provide waste-free and environmentally friendly production. Therefore, the development of methods and technological solutions allowing reducing the loss of materials is an important task.

Old bread returned from the commercial network is not allowed to be processed at bakery enterprises in Russia, but it can be used as a substrate for producing different substances, such as lactic acid and hydrogen [1], ethanol [2, 3], succinic acid [4, 5], xanthan gum [6] and sugars [7].

Bread is a valuable material because it contains starch, protein, minerals, fiber, and vitamins. The starch is in a gelatinized state, which makes it more accessible for the action of enzymes [8]. In this regard, white bread waste as a substrate for the production of baker's yeast and for the cultivation of starter cultures was investigated $[9,10]$.

But in addition to old bread returned from the commercial network, defect and substandard bread may be formed due to problems in the technological process. Serious attention has been paid to the resource saving in the bakery industry, especially since the beginning of the last century, when industrialization began and the large mechanized enterprises were built $[11,12]$. But the old bread recycle methods are not effective enough today $[12,13]$.

In the Russian bread making industry defect bread and waste recycled in the enterprises by adding to the dough [11-14]. In accordance with the "Rules for the Organization and Conducting the Technological Process at the Bakery Enterprises" three semi-finished products used in dough making process can be made from old bread and waste: bread crumbs, crumbs (crackers) and soaked bread (special semi-finished product) [11-13]. Some of the processed bread can be sold in the retail network for the production of homemade kvass or as bread crumbs for culinary [13-14]

Bread hydrolysates obtained under the action of enzymes may be used in the dough [11]. It is recommended to use old bread and defect bread in sourdoughs. Studies show that the use of recycled bread in the dough has a positive effect on the quality of the bread and the delay in staling [12-16].

A number of disadvantages are possible if old bread is used. Newly made bread may possess smell of old stale bread. Rapid bread microbial spoilage possible when spoiled bread (moldy, limy or ropy) was used [1216]. Besides soaked bread is an excellent medium for microbial spoilage pathogens. Therefore, soaked bread usage increases the risk of microbial contamination and moldy taste of bread [12].

The aim of this research was to develop a new resource-saving technology of liquid sourdough using recycled bread.

\footnotetext{
* Corresponding author: 1103 savkina@mail.ru
} 


\section{Materials and methods}

\subsection{Sourdough preparation}

$25,50,75$ and $100 \%$ of bread crumbs were used instead of flour (accounted in dry matter) in experimental sourdoughs. Nutrition mixture for control sourdough was made without the use of bread crumbs. Sourdough humidity was $70 \%$ [17]. The formulations for sourdoughs are given in Table 1.

Lactic acid bacteria (LAB) and yeasts strains were obtained from the St. Petersburg branch State Research Institute of Baking Industry. Four LAB strains (L. brevis 1, L.plantarum 30, L.casei 26, L. fermentum 34) and two yeasts strain (S.cerevisiae Y120 and C milleri) were used [17].

Table 1. Sourdough formulations.

\begin{tabular}{|c|c|c|c|c|c|}
\hline \multirow{2}{*}{$\begin{array}{c}\text { Ingredients, } \\
\%\end{array}$} & Control & \multicolumn{4}{|c|}{$\begin{array}{c}\text { Amount of bread crumbs in } \\
\text { experimental sourdough, \% }\end{array}$} \\
\cline { 3 - 6 } & & 25 & 50 & 75 & 100 \\
\hline Rye flour & 70.0 & 52.5 & 35.0 & 17.5 & - \\
\hline Bread crumbs & 0 & 26.5 & 53.0 & 79.5 & 106.0 \\
\hline Water & 134.0 & 125.0 & 116.0 & 107.0 & 98.0 \\
\hline
\end{tabular}

\subsection{Bread making procedure}

The control breads were prepared in two varieties: 1 . using sourdough without bread crumbs; 2. using sourdough without bread crumbs and bread crumbs were added in the dough in an amount equal to the content of crumbs in the experimental sourdough. The test bread was prepared using a liquid sourdough containing $25 \%$ bread crumbs instead of flour. The formulations for the rye-wheat breads are given in Table 2 .

Breads were prepared by mixing flour, sourdough, salt, yeast, bread crumbs (control bread with bread crumbs in the dough) and water. Then the dough were shaped into $400 \mathrm{~g}$ loaves, placed in aluminum pans and leavened at $30^{\circ} \mathrm{C}$ until the volume was increased. Breads were baked in oven at $210^{\circ} \mathrm{C}$ for $20 \mathrm{~min}$.
Table 2. Rye-wheat bread formulations.

\begin{tabular}{|c|c|c|c|}
\hline Ingredients, \% & $\begin{array}{c}\text { Control } \\
\text { bread }\end{array}$ & $\begin{array}{c}\text { Bread with } \\
\text { bread crumbs } \\
\text { in dough }\end{array}$ & $\begin{array}{c}\text { Bread with bread } \\
\text { crumbs in } \\
\text { sourdough }\end{array}$ \\
\hline Rye flour & 40 & 35 & 40 \\
\hline Wheat flour & 40 & 40 & 40 \\
\hline Sourdough & 52 & 52 & - \\
\hline $\begin{array}{c}\text { Sourdough } \\
\text { bread crumbs }\end{array}$ & - & - & 52 \\
\hline $\begin{array}{c}\text { Old bread } \\
\text { crumbs }\end{array}$ & - & 6.3 & - \\
\hline Pressed yeast & 0.5 & 0.5 & 0.5 \\
\hline Salt & 1.4 & 1.4 & 1.4 \\
\hline Water & \multicolumn{3}{|c|}{ until dough humidity of $43 \%$} \\
\hline
\end{tabular}

\subsection{Nutrition mixture, sourdough and dough assessments}

The sourdough rheological properties (dynamic viscosity) were investigated using a rotary viscometer (Reotest-2, Germany) at a shear rate of $0.9 \mathrm{~s}-1$ and temperature of $28-30{ }^{\circ} \mathrm{C}$. Sourdough mass was $50 \mathrm{~g}$. Viscosity was calculated using the formula given in the instructions for device (in $\mathrm{Pa} \bullet \mathrm{s}$ ).

Nutrition mixtures for sourdoughs preparation (flour, water and bread crumbs in different proportion given in Table 1) were investigated. The sugar content in the sourdough nutrition mixtures was determined using Bertrand's method, which is based on the collection of copper oxide precipitate formed during the reduction of an alkaline copper solution in the presence of reducing sugars and analyzed by the manganimetric method [18].

Sourdough, nutrition mixture and dough quality were evaluated next way: acidity was determined by titration, using a 0.1 n. solution of $\mathrm{NaOH}$ [19]. The lifting capacity was determined as time of floating of $10 \mathrm{~g}$ dough balls in water at $32^{\circ} \mathrm{C}$ [19]. The increase in volume was evaluated as ratio between the final volume and the initial volume multiplied by $100 \%$.

The content of volatile acids was determined by neutralizing the evaporated volatile acid using a $0.1 \mathrm{n}$. solution of $\mathrm{NaOH}$ [19]. The alcohol content was determined by using the iodometric method, which is based on the detection of sodium thiosulfate quantity spent in titration [19].

LAB and yeast amount in a sourdough and in nutrition mixture were evaluated using the method of microscopy and counting in a fixed colored preparation in 50 fields of view [20].

\subsection{Bread assessment}

Sensory (shape, surface, crumb color, porosity and texture, taste and smell) and physic-chemical characteristics were evaluated in baked bread. 


\subsubsection{Assessment of quality}

Titratable acidity was determined by titration with $0.1 \mathrm{~N}$ solutions of $\mathrm{NaOH}$ [18]. Pore volume was evaluated as the ratio of crumb pore volume to the total bread volume, pore volume was determined as the difference between the volume of product and the volume of nonporous mass. Specific volume was evaluated as the ratio of bread volume and mass (100 g of bread). Crumb compressibility was determined on the automatic penetrometer Labor (Hungary). The crumbliness of the crumb was investigated in a 24 and $96 \mathrm{~h}$ of storage [18].

The volatile acids content was estimated by neutralizing the evaporated volatile acid using a $0.1 \mathrm{n}$. solution of $\mathrm{NaOH}$. The alcohol content was determined by iodometric method based on sodium thiosulfate titration [18].

\subsubsection{Sensory evaluation}

10-member expert panel evaluated the bread organoleptic characteristics. Experts evaluated smell and taste, crumb texture, crust color and porosity. Each trait was evaluated on a scale from 1 to 5: 1 - dislike extremely; 2 - dislike; 3 - slightly dislike; 4 moderately; 5 - very good.

\subsubsection{Microbial spoilage assessment}

The impact of the old bread crumbs on mould and ropy disease of newly made bread was investigated. Sterile bread slices were contaminated by a pure culture of the mould Penicillium chrysogenum. Method described in details in previous study [13]. Bread after cooling was stored at $37^{\circ} \mathrm{C}$ and air humidity $80 \pm 5{ }^{\circ} \mathrm{C}$ before the appearance of ropy disease [19]. Ropy bread disease appearance was monitored in a 16 hours and every next 4 hours.

\subsection{Statistical analysis}

All experiments were carried out three times. Statistical analysis was conducted using Excel software. Comparison of the different factors influence was carried out using the method with significance tested at the $95 \%$ confidence level and differences among means were determined using the least significant difference and Duncan's test of two-factor analysis of variance with one repetition (ANOVA). Results were given as mean \pm standard deviation.

\section{Results}

The influence of the recycled bread crumbs quantity on liquid sourdough biotechnological indicators was investigated (Table 3).
Table 3. Influense of bread crumbs on sourdough biotechnological indicators.

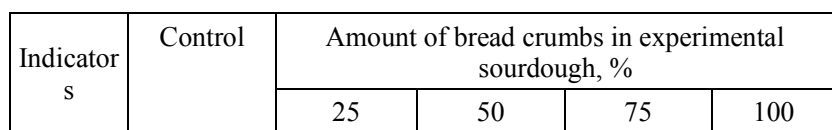

Nutrient mixture for sourdough (flour/bread crumbs + water)

\begin{tabular}{|c|c|c|c|c|c|}
\hline $\begin{array}{l}\text { Acidity, } \\
\text { degrees }\end{array}$ & $2.3 \pm 0.2^{\mathrm{a}}$ & $3.3 \pm 0.2^{b}$ & $4.4 \pm 0.2^{\mathrm{c}}$ & $4.8 \pm 0.3^{\mathrm{d}}$ & $5.6 \pm 0.3^{\mathrm{f}}$ \\
\hline $\begin{array}{r}\text { Reducing } \\
\text { sugar, \% }\end{array}$ & $3.7 \pm 0.2^{\mathrm{a}}$ & $6.3 \pm 0.3^{\mathrm{b}}$ & $6.5 \pm 0.4^{\mathrm{b}}$ & $6.5 \pm 0.4^{\mathrm{b}}$ & $3.7 \pm 0.2^{\mathrm{c}}$ \\
\hline $\begin{array}{c}\text { Lactobac } \\
\text { illi, } 10^{7} \\
\text { cells } \cdot \mathrm{g}^{-1} \\
\end{array}$ & $10.0 \pm 0.1^{\mathrm{a}}$ & $10.0 \pm 0.1^{\mathrm{a}}$ & $1.0 \pm 0.01^{\mathrm{b}}$ & - & - \\
\hline \multicolumn{6}{|c|}{ Sourdough after fermentation } \\
\hline $\begin{array}{l}\text { Acidity, } \\
\text { degrees }\end{array}$ & $9.3 \pm 0.2^{\mathrm{a}}$ & $9.8 \pm 0.2^{\mathrm{b}}$ & $11.3 \pm 0.2^{\mathrm{c}}$ & $10.0 \pm 0.3^{b}$ & $8.4 \pm 0.2^{\mathrm{d}}$ \\
\hline $\begin{array}{c}\text { Lifting } \\
\text { capacity } \\
\text { min }\end{array}$ & $24 \pm 1^{a}$ & $17 \pm 1^{\mathrm{b}}$ & $32 \pm 2^{c}$ & $39 \pm 3^{d}$ & $52 \pm 3^{\mathrm{f}}$ \\
\hline $\begin{array}{c}\begin{array}{c}\text { Volume } \\
\text { incre- } \\
\text { asing, } \%\end{array} \\
\end{array}$ & $52 \pm 1^{a}$ & $51 \pm 1^{\mathrm{b}}$ & $16 \pm 1^{\mathrm{c}}$ & $8 \pm 1^{d}$ & $8 \pm 1^{\mathrm{d}}$ \\
\hline $\begin{array}{r}\text { Volatile } \\
\text { acids, } \%\end{array}$ & $23.9 \pm 1.3^{\mathrm{a}}$ & $30.5 \pm 2.0^{\mathrm{b}}$ & $28.8 \pm 1.2^{\mathrm{c}}$ & $29.2 \pm 1.2^{\mathrm{c}}$ & $28.7 \pm 1.0^{\mathrm{c}}$ \\
\hline $\begin{array}{c}\text { Alcohol, } \\
\% \text { of dry } \\
\text { weight }\end{array}$ & $3.5 \pm 0.3^{\mathrm{a}}$ & $5.2 \pm 0.3^{\mathrm{b}}$ & $2.4 \pm 0.2^{\mathrm{c}}$ & $1.8 \pm 0.2^{\mathrm{d}}$ & $1.9 \pm 0.2^{\mathrm{d}}$ \\
\hline $\begin{array}{c}\text { Lactobac } \\
\text { illi, } 10^{9} \\
\text { cells } \cdot \mathrm{g}^{-1} \\
\end{array}$ & $2.2 \pm 0.2^{\mathrm{a}}$ & $1.9 \pm 0.2^{\mathrm{a}}$ & $0.9 \pm 0.1^{\mathrm{b}}$ & $0.8 \pm 0.1^{\mathrm{b}}$ & $0.5 \pm 0.2^{\mathrm{c}}$ \\
\hline $\begin{array}{l}\text { Yeasts, } \\
10^{8} \\
\text { cells } \cdot \mathrm{g}^{-1}\end{array}$ & $0.7 \pm 0.1^{\mathrm{a}}$ & $0.7 \pm 0.2^{\mathrm{a}}$ & $0.8 \pm 0.2^{\mathrm{a}}$ & $0.7 \pm 0.2^{\mathrm{a}}$ & $0.2 \pm 0.1^{\mathrm{ba}}$ \\
\hline
\end{tabular}

$\mathrm{a}-\mathrm{f}=$ Means $\pm \mathrm{SD}$ within the same line with different lowercase superscript letters are significantly different $(\mathrm{P} \leq 0.05)$

Since the composition and quality of the nutrient mixture greatly influences the sourdough biotechnological parameters, the content of reducing sugars, LAB and the acidity in nutrient mixtures used for the sourdough preparation were studied.

The initial acidity of the nutrition mixture for sourdough before fermentation increased along with an increase in the amount of bread crumbs. The content of reducing sugars, which are fermentable sugars and feeding for LAB and yeasts, was higher in a nutrition mixture made with $25-75 \%$ of bread crumbs. In a nutritional mixture made from $100 \%$ of bread crumbs, the amount of reducing sugars was the same as in the control.

It was found that in the nutrient mixtures prepared without bread crumbs and nutrient mixtures with $25 \%$ and $50 \%$ of bread crumbs, the content of LAB was $10 \times$ $10^{8}$ cells $\cdot \mathrm{g}^{-1}$. With an increase of bread crumbs dosage up to $50 \%$, the LAB amount in the nutrient mixture decreased in 10 times, and with a further increase up to $75 \%$ and $100 \%, \mathrm{LAB}$ in the nutrient mixture were not detected at all.

With increasing in the bread crumbs dosage from 50 to $100 \%$, biotechnological indicators deteriorated: acid accumulation slowed down, lifting force get worth (Table 3). Despite the fact that the content of LAB and yeast was the same in the control and in the sourdough 
with $25 \%$ of bread crumbs, the sourdough with $25 \%$ of bread crumb had better lifting power and the content of alcohol and volatile acids in it was higher compared to the control.

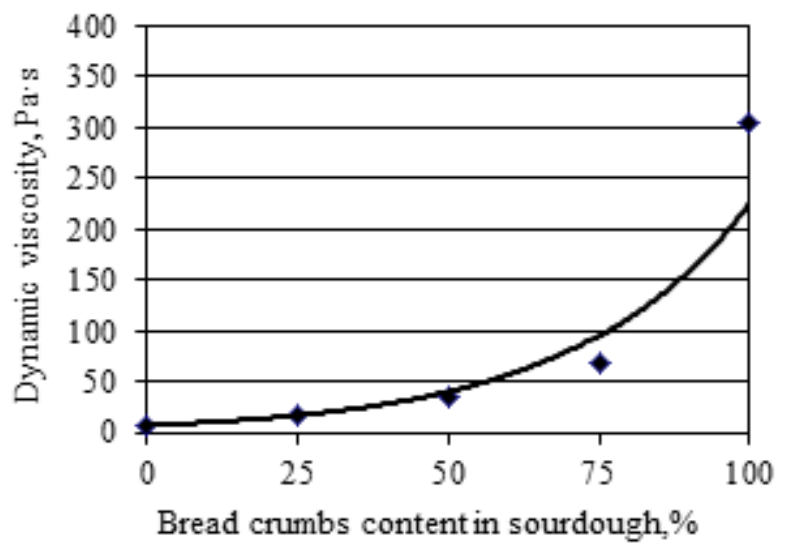

Fig. 1. Sourdough dynamic viscosity.

Sourdough viscosity was investigated. The viscosity increased when bread dosage increased, which may makes it difficult or impossible to transport and to dose the sourdough using pump (Fig. 1).

The data obtained showed that the optimal dosage was $25 \%$ of bread crumbs in sourdough.

The influence of liquid rye sourdough contained $25 \%$ of recycled bread crumbs on the new bread quality and its microbiological safety was investigated. It was found that the experimental bread samples in terms of physical, chemical and organoleptic characteristics were close to the control (Table 4, Fig. 2). Porosity, specific volume and compressibility were comparable in all samples. In bread made with sourdough containing $25 \%$ of bread crumbs was higher content of volatile acids and alcohol. This had a positive effect on its taste and smell (Fig. 2).

The crumbliness of the breads made with bread crumbs in sourdough was 2 times lower than that of the control samples.

The effect of the bread crumbs on the bread resistance to the microbial spoilage was established. When contaminated bread by Penicillium chrysogenum, the mould colonies hadn't gown on bread slices until total slice staling. No science if ropy disease was observed in all bread samples.
Table 4. Phisyco-chemycal indicators of bread.

\begin{tabular}{|c|c|c|c|}
\hline Indicators & Control & $\begin{array}{c}\text { Made with } \\
\text { bread crumbs } \\
\text { in dough }\end{array}$ & $\begin{array}{c}\text { Made with } \\
\text { bread crumbs } \\
\text { in sourdough }\end{array}$ \\
\hline Acidity, degrees & $8.0 \pm 0.2^{\mathrm{a}}$ & $7.6 \pm 0.2^{\mathrm{b}}$ & $7.8 \pm 0.3^{\mathrm{b}}$ \\
\hline Pore volume, \% & $68 \pm 2^{\mathrm{a}}$ & $66 \pm 2^{\mathrm{a}}$ & $67 \pm 2^{\mathrm{a}}$ \\
\hline $\begin{array}{c}\text { Specific volume, } \\
\text { cm3 g }{ }^{-1}\end{array}$ & $2.0 \pm 0.2^{\mathrm{a}}$ & $2.0 \pm 0.2^{\mathrm{a}}$ & $2.1 \pm 0.2^{\mathrm{a}}$ \\
\hline $\begin{array}{c}\text { Quantity of } \\
\text { alcohol, \% of dried } \\
\text { weight }\end{array}$ & $0.88 \pm 0.05^{\mathrm{a}}$ & $0.87 \pm 0.05^{\mathrm{a}}$ & $0.96 \pm 0.04^{\mathrm{b}}$ \\
\hline $\begin{array}{c}\text { Volatile acids, \% } \\
\text { of the total acidity }\end{array}$ & $20.0 \pm 0.2^{\mathrm{a}}$ & $21.7 \pm 0.1^{\mathrm{b}}$ & $25.0 \pm 0.3^{\mathrm{c}}$ \\
\hline $\begin{array}{c}\text { Compressibility in } \\
\text { a 24 h, unite of } \\
\text { device }\end{array}$ & $20 \pm 2^{\mathrm{a}}$ & $21 \pm 2^{\mathrm{a}}$ & $21 \pm 3^{\mathrm{a}}$ \\
\hline $\begin{array}{c}\text { Compressibility in } \\
\text { a 96 h, unite of } \\
\text { device }\end{array}$ & $10 \pm 2^{\mathrm{a}}$ & $11 \pm 2^{\mathrm{a}}$ & $11 \pm 2^{\mathrm{a}}$ \\
\hline $\begin{array}{c}\text { Crumbliness in a } \\
24 \mathrm{~h}, \%\end{array}$ & $6.4 \pm 0.2^{\mathrm{a}}$ & $6.3 \pm 0.2^{\mathrm{a}}$ & $3.1 \pm 0.2^{\mathrm{b}}$ \\
\hline $\begin{array}{c}\text { Crumbliness in a } \\
96 \mathrm{~h}, \%\end{array}$ & $9.2 \pm 0.2^{\mathrm{a}}$ & $6.6 \pm 0.2^{\mathrm{a}}$ & $2.9 \pm 0.2^{\mathrm{b}}$ \\
\hline
\end{tabular}

a-c $=$ Means \pm SD within the same line with different lowercase superscript letters are significantly different $(\mathrm{P} \leq$ $0.05)$

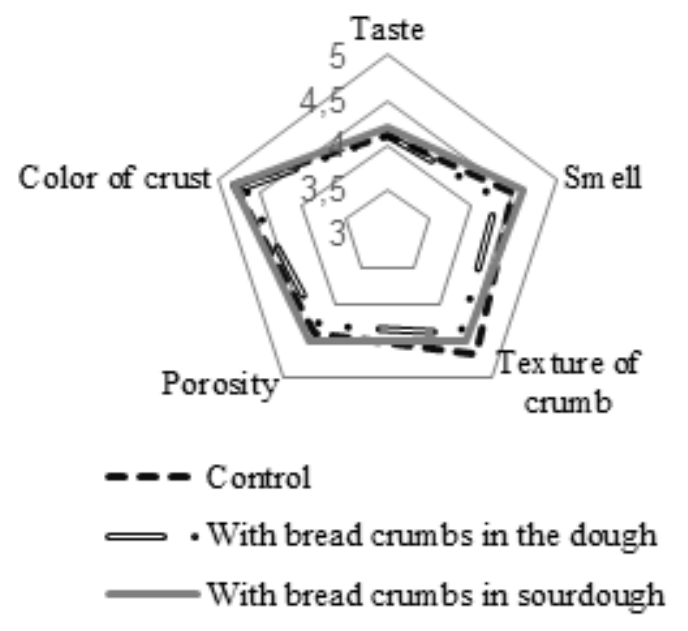

Fig. 2. Organoleptic characteristics of breads.

\section{Discussions}

New data on the influence of the nutritional mixture composition and the bread crumbs content on the liquid sourdough biotechnological parameters were obtained in these studies. At the present time, the data on influence of old bread on sourdough, dough and bread is limited in the scientific literature. The data obtained by us in this and in previous work [13] have shown that recycled bread has a different effect on various sourdough types possessing different humidity and microbial content.

The increasing in nutrient mixture acidity with old bread addition may be due to the high acidity of ryewheat bread $[8,13]$. But in the fermented sourdoughs containing $50-100 \%$ of bread crumbs the acidity decreased compared to the sourdoughs with $25 \%$ bread crumbs. 
The data on the sugar content showed that the slowing of acid-forming activity with an increase in the bread crumb dosage was not associated with a sugar deficiency, since the content of reducing sugars in the sourdough with bread crumbs was higher than in the control (Table 3). The high content of reducing sugars in sourdough with bread is confirmed by other studies [13, $15,16]$. When the amount of old bread increased up to $75 \%$, the content of reducing sugars increased too. In sourdough with $100 \%$ of old bread sugars content decreased and was comparable to the control. The data obtained for the liquid sourdough differ from the data obtained earlier for the dense rye sourdough. The dense sourdough contained more quantity of reducing sugars [13]. In addition, at $100 \%$ replacement of flour in with bread crumbs, more quantity of reducing sugars were found in dense sourdough than in the control. Obviously, this may be due to the difference in the moisture content of sourdough.

It was found that in the nutrient mixtures prepared without bread crumbs and with $25 \%$ and $50 \%$ of bread crumbs, the content of LAB was $10 \times 10^{8}$ cells $\cdot \mathrm{g}^{-1}$. With an increase in the amount of bread crumbs up to $50 \%$, the LAB amount in the nutrient mixture decreased in 10 times and with increase in the bread crumbs content up to $75 \%$ and $100 \%, \mathrm{LAB}$ in the nutrient mixture were not detected. Consequently, the content of spontaneous fermenting microflora in the nutritional mixture with an increase in the dosage of bread crumbs was significantly reduced. The study of the microflora of the fermented liquid rye sourdough showed that replacing 25, 50, 75 and $100 \%$ of flour with bread crumbs also showed a decrease in the content of lactic acid bacteria. Thus, the decrease in the acidity of the experimental sourdough was possibly due to a decrease in the content of spontaneous microflora in the nutrient mixture introduced with flour and participating in the acid formation process along with starter microorganisms introduced during sourdough propagation [13, 18, 21].

Despite the slowing down of acid formation and a smaller amount of lactic acid bacteria in the sourdoughs made with $50-100 \%$ of bread crumbs, the content of volatile acids in it was higher. This may be due to the dominance of heterofrementative LABs, as well as to the fact that rye-wheat bread crumbs also contain a large amount of volatile acids [13, 19, 21].

The sourdoughs made with $50-100 \%$ of bread crumbs increased significantly less in volume. This may be due to the fact that the native proteins and carbohydrates of rye flour have been replaced by bread degraded ones. [8, 18]. Bread crumbs polymers were degraded during baking and have lost native properties. They differ from polymers of native flour $[8,21,22]$. Since the amount of yeast was comparable and the amount of fermentable sugars was higher in the sourdoughs with bread crumbs than in the control, the volume reduction was not associated with low fermentation activity [8, 19, 23]. The sourdough volume was lower because of native biopolymers degradation.

It is also of great importance to develop resourcesaving technologies that would economic advantages for the manufacturer and would not require significant changes in the baking technological process and new equipment. The success of the introduction of new technologies largely depends on the convenience of their application at already operating enterprises. Therefore, in our work, we tried to optimize and make available the bread recycling in successfully operating bakery enterprises. So, sourdough viscosity was evaluated, as it one of the important characteristics for liquid sourdough transporting. With an increase in the bread crumbs dosage more than $25 \%$, the viscosity increased significantly, even with careful homogenization and grinding. It is also due to the change in bread biopolymers compared to native flour.

The lower crumbliness of the breads with bread crumbs have shown that the sourdough with bread crumbs allowed slowing down the staling of bread. This data confirmed data obtained by other researchers [14, 15]

Fermentation of bread crumbs in sourdough has a beneficial effect on the bread quality indicators. The content of alcohol and volatile acids in bread made with sourdough with $25 \%$ of bread crumbs (Table 2) was higher than in the control. This provided the improvement of the taste and smell of bread made with $25 \%$ of bread crumbs in sourdough. Comparison with the data obtained earlier showed that the sourdough type influenced the content of volatile acids [13].

The absence of mold and ropy-disease in infected bread indicated that bread recycling had not increased the risk of the bread microbial spoilage. This may be due to the antimicrobial activity of $\operatorname{LAB}[25,26]$.

So the influence of bread crumbs in sourdough on the bread quality was shown. It is obvious that the bread crumb usage in the sourdough allowed increasing the amount of processed bread in comparison with the Russian norms. The use of bread crumbs in sourdough have not negatively affect the bread quality and have not increase the risk of microbial spoilage.

\section{Conclusions}

The data obtained showed that the amount of fermentable (reducing) sugars in the sourdoughs with bread crumbs was higher, and the yeast content was comparable to the control traditional sourdough. Thus, a decrease in the sourdough volume has not associated with deterioration in fermentation activity. It was due to the fact that native biopolymers (proteins and starch) were degraded in bread and could not retain gas bubbles.

It was found that an increase in the amount of bread crumb over $25 \%$ significantly increased the viscosity. This may make impossible transporting of sourdough by pumps in bread-making enterprises.

The sourdough containing $25 \%$ of bread crumbs had a higher acidity, higher content of volatile acids and alcohol than the control. The amount of lactic acid bacteria and yeast was comparable in both cultures. This is due to the fact that bread is a good nutrient mixture.

When the bread crumbs were fermented in sourdough, the crumbliness of the newly made bread was two times less during storage. This showed the 
slowing of the staling process compared to bread based on traditional sourdough and bread made using bread crumbs in the dough.

Based on the results of the study, it is obviously that bread crumbs usage in the sourdough allows increasing the amount of recycled bread in comparison with the Russian norms.

\section{References}

1. A. Adessi, M. Venturi, F. Candeliere, V. Galli, L. Granchi, R. De Philippis, Int. J. Hydrog. Energy, 43 (20), 9569-9576 (2018)

2. S. Torabi, B. Satari, Biomass Conversion and Biorefinery (2020)

3. S. Haroon, A. Vinthan, L. Negron, S. Das, A. Berenjian, Am. J. of Biochem. and Biotechnol., 12, 102-109 (2016)

4. F. Koon, C. Cho, M. Ho, S.L. Carol, Food Bioprod. Process., 92, 282-290 (2014)

5. C.C.J. Leung, A.S.Y. Cheung, A. Y.-Z. Zhang, K.F. Lam, C.S.K. Lin, Biochem. Eng. Journal., 65, 10-15 (2012)

6. A.S. Demirci, I. Palabiyik, D. Apaydın, M. Mirik, T. Gumus, LWT, 101, 40-47 (2019)

7. N. Thani, S.M.M. Kamal, F. Taip, A. Sulaiman, R. Omar, Food and Bioproducts Processing, 117, 105-112 (2019)

8. S.P. Cauvain, L.S. Young, Technology of Breadmaking, second ed. (Springer, BakeTran, UK, 2007, 397)

9. O. Benabda, M. Kasmi, F. Kachouri, M. Hamdi, Food Bioprod. Process, 109, 1-8 (2018) DOI: 10.1016/j.fbp.2018.02.007

10. M. Verni, A. Minisci, S. Convertino, L. Nionelli, C.G. Rizzello, Frontiers in Microbiology (2020)

11. A. Kosovan, Rules for the organization and conduct of the technological process at the baking enterprises (GOSNIIHP, Moscow, 1999)

12. L. Kuznetsova, O. Savkina, L. Usova, Bread products, 3 (2017)

13. O. Savkina, L. Kuznetsova, M. Lokachuk, O. Parakhina, E. Pavlovskaya, N. Lavrenteva, E3S Web of Conferences, 161, 01082 (2020)

14. Bread + Pastries and Confectionery (Almanac, Hamburg, 2011)

15. M. Immonen, H. Ndegwa, Y. Wang, R. Coda, K. Katina, International Journal of Food Microbiology (2020)

16. M. Verni, A. Minisci, S. Convertino, L. Nionelli, C.G. Rizzello, Front. Microbiology (2020)

17. A. Kosovan, The collection of modern technology of bakery products (Moscow printing house, Moscow, 2008)

18. O. Savkina, L. Kuznetsova, M. Burykina, M. Kostyuchenko, O. Parakhina, Agronomy Research, 18 (3) (2020)

19. L. Puchkova, Laboratory Workshop on Bakery Technology (GIORD, Saint-Petersburg, 2004)

20. O. Afanasjeva, Microbiology of bakery production (Beresta, Saint-Peterburg, 2003)
21. M.G. Gänzle, Food Microbiol., 37, 2-10 (2014) DOI: $10.1016 /$ j.fm.2013.04.007

22. A.S. Sivam, D. Sun-Waterhouse, S. Quek, C.O. Perera, Journal of Food Science, 75, 8 (2010)

23. M. Schirmer, M. Jekle, T. Becker, Procedia Food Science, 1 (2011)

24. C. Kurtzman, J.W. Fell, T. Boekhout, The Yeasts, A Taxonomic Study, 5th edition (Elsevier, Amsterdam, 2011)

25. Y.I. Hassan, T. Zhou, L.B. Bullerman, Food Science and Technology International, 22 (1) (2015)

26. G. Zhang, J. Tu, F.A. Sadiq, W. Zhang, W. Wang, Comprehensive Reviews in Food Science and Food Safety (2019) 